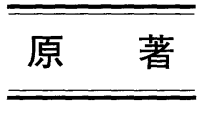

\title{
腟スメア上に検出されるカンジ夕゙属に関する 形態学的検討
}

\author{
東邦大学医学部付属大橋病院病理部 ${ }^{11}$, 同 第 2 産婦人科 ${ }^{2}$, 医療法人社団仁厚会安田診療所 ${ }^{31}$ \\ 田口 勝二1） 岩原 実 ${ }^{1)}$ 藤田 正志 ${ }^{12}$ 村石 佳重 ${ }^{1)}$ \\ 渡辺 裕子 ${ }^{11}$ 渋谷 和俊 ${ }^{1)}$ 安田 貢 ${ }^{3)}$ 寺内 文敏 ${ }^{21}$ \\ 小倉 久男 ${ }^{21}$ 直江 史郎 ${ }^{11}$
}

腔スメア中に酵母様真菌を認め, さらにカンジダ属が分離同定された 47 例を対象として主に酵 母細胞の形態的検討を行い, 細胞診検体の検鏡による種の推定とその精度について検討した. その 結果, C. albicans 酵母細胞は長径 $4 \mu$ 以上が多く, 最も多くの小型酵母細胞をみた症例でさえも $49 \%$ は長径 $4 \mu$ 以上の酵母細胞であった。また, ほとんどの症例に仮性菌系が観察された。C. glabrata は $98.5 \%$ が長径 $4 \mu$ 以下の酵母細胞であり, 長径 $5 \mu$ 以上の酵母細胞はきわめてまれで あった.C. krusei は $4 \mu$ 以上の酵母細胞としてみられたが, $6 \mu$ 以上のものが多く, C. albicans に比べ長棈円形の酵母細胞が多かった。

以上の結果は, 腔真菌症の原因菌として重要な C. albicans と C. glabrata を細胞診で鑑別しうる 可能性を示唆するものであり, 早期診断や治療に役立つと考元られた.

Key words : Vaginal candidosis_-Cytology_-Vaginal smear-Candida albicansCandida glabrata

\section{I.はじめに}

日常, 胵スメア中に酵母様真菌をみることはまれで はなく，その大半はカンジダ属である ${ }^{1 \sim 4)}$. このカン

\footnotetext{
Morphological study on Candida species in vaginal smears Katsuji TAGUCHI ${ }^{1}$, C.T., Minoru IWAHARA ${ }^{1)}$, C.T., Masashi FUJITA ${ }^{1)}$, C.T., Yoshie MURAISHI ${ }^{1)}$, C.T., Yuko WATANABE $^{1)}$, C.T., Kazutoshi SHIBUYA ${ }^{1)}$, M.D., Mitsugu YASUDA $^{3)}$, M.D., Fumitoshi TERAUCHI ${ }^{2)}$, M.D., Hisao OGURA $^{2)}$, M.D., Shiro NAOE ${ }^{1)}$, M.D.

${ }^{1)}$ Department of Pathology, ${ }^{2}$ Second Department of Obstetrics and Gynecology, Toho University School of Medicine, Ohashi Hospital

${ }^{3)}$ Yasuda Clinic

論文別刷請求先 $\bar{\top} 153$ 東京都目黒区大橋 2 の 17 の 6 東邦 大学医学部付属大橋病院病理部 田口勝二

平成 8 年 6 月 19 日受付

平成 8 年 10 月 18 日受付
}

ジダ属は Candida albicans（=C. albicans）を始め とし多くは二形性 (dimorphism)，すなわち酵母型と 菌系型の二つの異なる形態を示すが，C. glabrataは いかなる発育条件でも二形性がみられない.

さて腔カンジダ症の原因菌の大半はこの C. albicans と C. glabrataの二者で占められているといわ れ, 症例数は圧倒的に前者に多いとされてきた ${ }^{5,6)}$. しかし近年, 本症の原因菌種に変化がみられ, 特に本 邦では後者によるものが増加し, 腔カンジダ症の 20 〜 $50 \%$ にも達しているとの報告もある7). また，一般 的に C. glabrataによる腔カンジダ症は, C. albicans によるものよりも症状は軽度ながらも難治性であると され，両者を迅速に区別することは治療上意義のある ことと思われる ${ }^{5 \sim 8)}$. しかし, 細胞診領域においてこ の 2 者に関した詳細な形態学的検討は少なく, 特に酵 母型の菌要素のみでは C. albicans と C. glabrata の鑑 
別はきわめて困難であるというものが多い9,10)。そこ で, 胵スメアにみられたこれら酵母様真菌に対して形 態的な検索を行い, 菌種推定の可能性およびその精度 について検討した。

\section{II. 材料および方法}

本院婦人科外来にて, 胵スメア中に酵母様真菌要素 を認め,また，同時にカンジダ属が分離同定された 47 例 (C. albicans 34 例, C. glabrata 10 例, C. albicans と C. glabrata が同時に分離された 1 例, $C$. krusei 2 例）を検索材料として以下の検討を行った。

\section{1. パパニコロウ染色標本による観察}

パパニコロウ染色にて観察される酵母細胞数を半定 量的に分け, さらに個々の酵母細胞の染色性について 検討した。

\section{2. 酵母細胞の形態に関する検討}

パパニコロウ染色脱色後, PAS 反応を施行した. このとき, シッフ氏液は酵母細胞への特異性を高める ため, $0.25 \%$ 曋硫酸水素ナトリウムで 100 倍に希釈 した液を使用した。

酵母細胞を観察後, 中間レンズ FK 6.7, 対物レン ズ 40 倍で撮影した。また, 個々の標本の撮影の最後 にオブジェクトマイクロメーター（ゲージ：1目盛り $10 \mu$ ，オリンパス社製）を対物レンズ 4 倍で撮影し, すべて同倍率で印画紙に焼き付けた。この写真の酵母 細胞を切り取り小さい酵母細胞の順に並べた。このと き, 隣接する酵母細胞は一塊として切り取り, 個々の 細胞の大きさと形態を比較した。 また, 酵母細胞の大 きさをわかりやすくするために 1 目盛りが 1 凡になっ たゲージの写真を縦, 横にはりつけた.

さらにC. albicans で最も小型の酵母細胞が多く観 察された 1 症例, 任意に抽出したC. glabrata 2 例お よび C. krusei 1 例の酵母細胞については, 接眼顕微 計測器（OSM-D 2, オリンパス社製）を使用して酵 母細胞の長径および短径を計測した。

\section{III. 結 果}

\section{1. パパニコロウ染色標本による観察（表 1)}

C. albicans 分離例：酵母細胞は, 長径 $4 \mu$ 以下の 酵母細胞も認めるが長径 $4 \mu$ 以上のものが多く, 34 例中 29 例に仮性菌系が確認できた. 菌体の多くは, パパニコロウ染色でオンンジGに淡染もしくは好染性
表 1 全例のパパニコロウ染色による観察

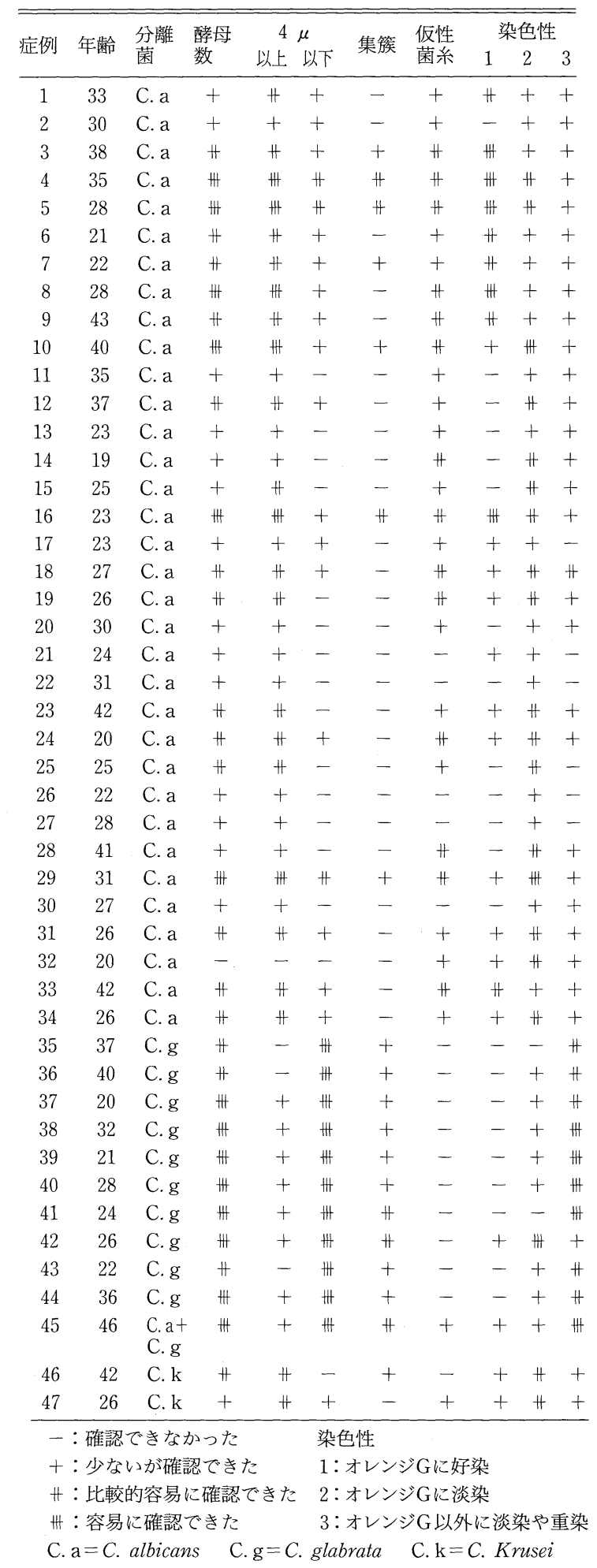




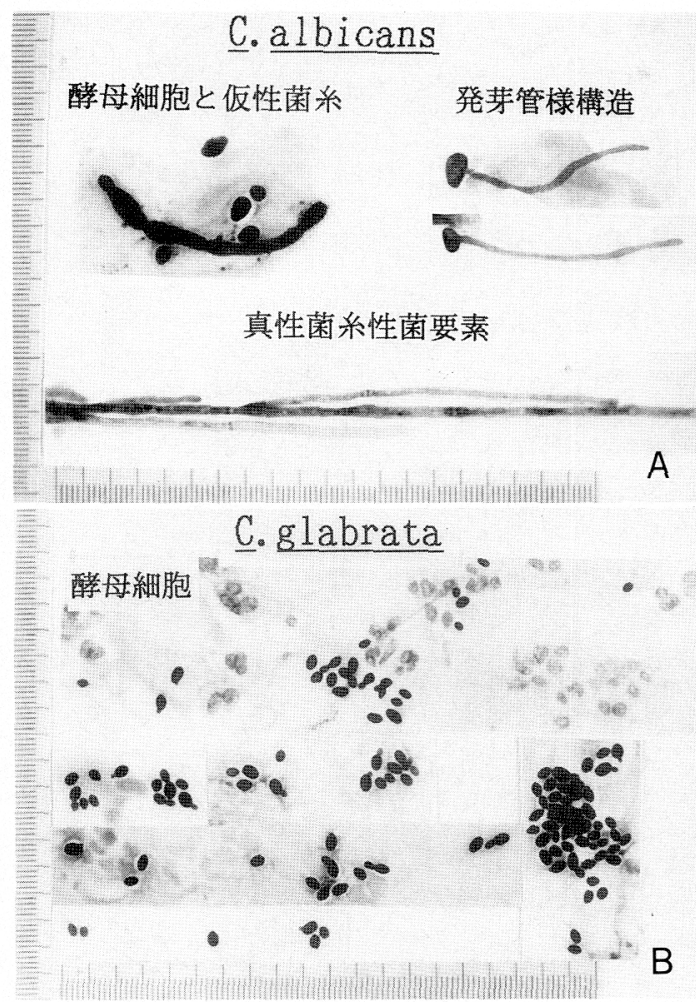

写真 1 A : C. albicans 例で観察された代表的所見の要約, B：C. glabrata 例で観察された代表的所見の要約

を示すが，ライトグリーンやビスマルクブラウン， ヘ マトキシリンなどの色素に淡染性を示すもの，あるい は重染性を示すものもみられた。

C. glabrata 分離例：酵母細胞のほとんどは, 長径 4 $\mu$ 以下で，菌体はパパニコロウ染色でオレンジ Gに好 染あるいは淡染するものもみられたが，その他の色素 に淡染や重染するものが多かった。

C. albicans，C. glabrata 同時分離例：酵母細胞の ほとんどは長径 $4 \mu$ 以下で，一部に仮性菌系がみられ た。

C. krusei 分離例：2 例とも長径 $5 \mu$ 以上の細長い酵 母細胞が多く観察された。酵母細胞の菌体は，パパニ コロウ染色でオレンジ Gに好染性を示すものが多いも のの，その他の色素と重染したものもみられた。

2. PAS 反応標本を用いた酵母細胞の形態に関す る検討（写真 $1 \sim 13$, 図 1 )

C. albicans 分離例：34 例中 33 例に仮性菌系が確認 され，この一部には真性菌系性菌要素も認められた。 さらに，10例に発芽管様構造をみた。酵母細胞の形 態注，卵円形を中心に一端がやや膨らみ，さまざまな

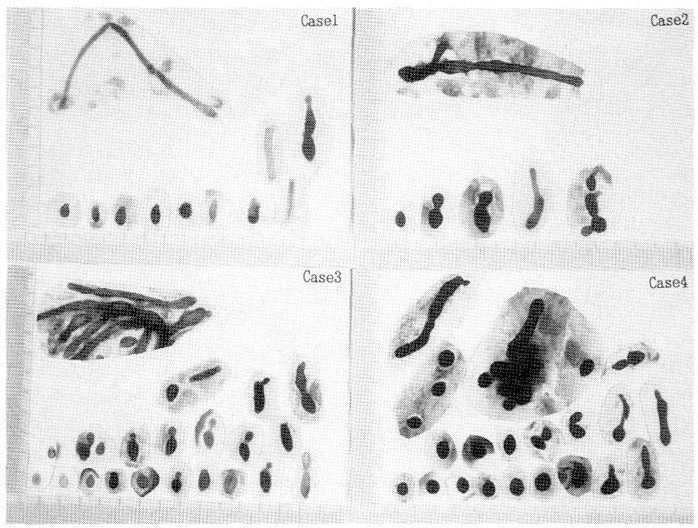

写真 2 酵母細胞の形態, Case 1〜4（C. albicans）

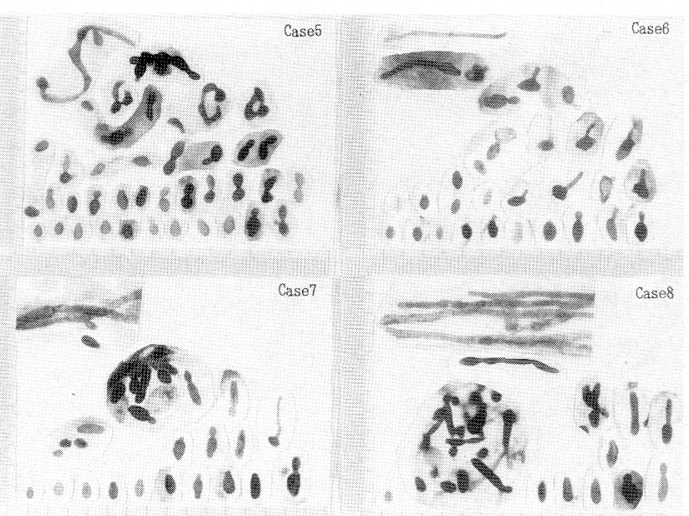

写真 3 酵母細胞の形態, Case 5〜8 (C. albicans)

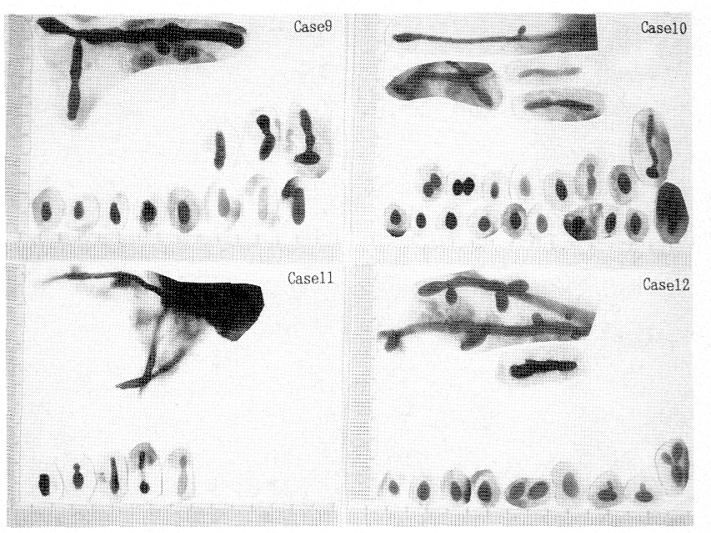

写真 4 酵母細胞の形態, Case 9〜12（C. albicans）

形態を示していた。また，すべての症例で標本上の酵 母細胞の長径は 5〜 6 $\mu$ が主体であった。長径 $4 \mu$ 以 下の小型酵母が最も多く観察され顕微計測を行った症 


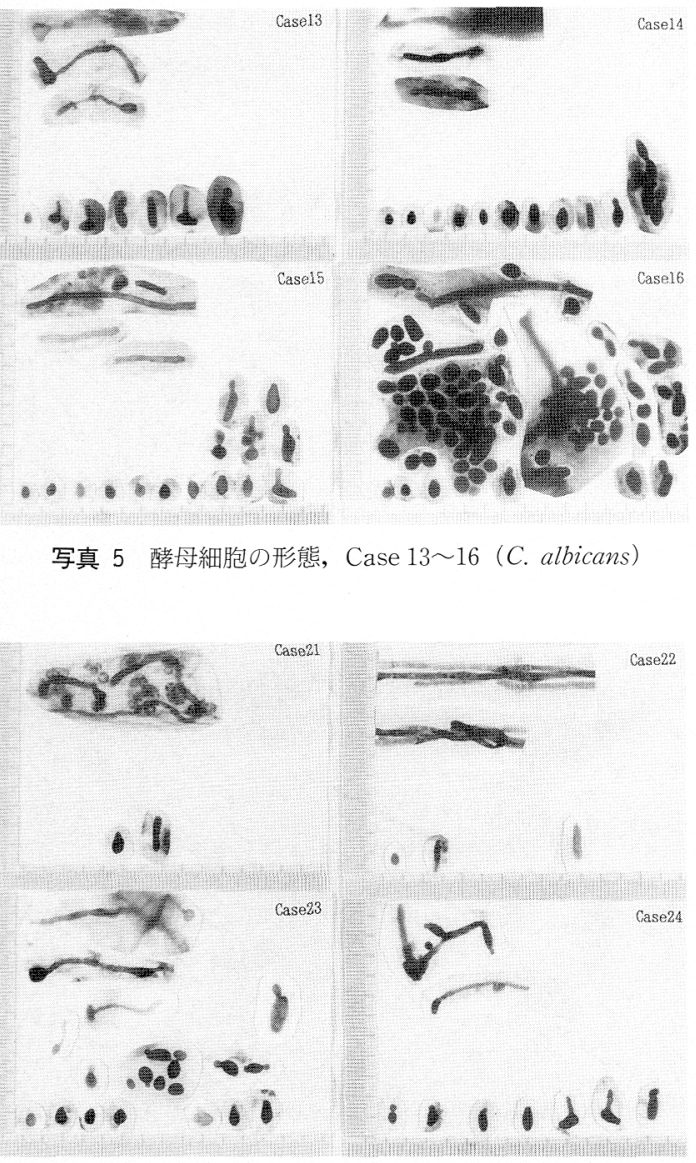

写真 7 醭母細胞の形態, Case 21 24（C. albicans）

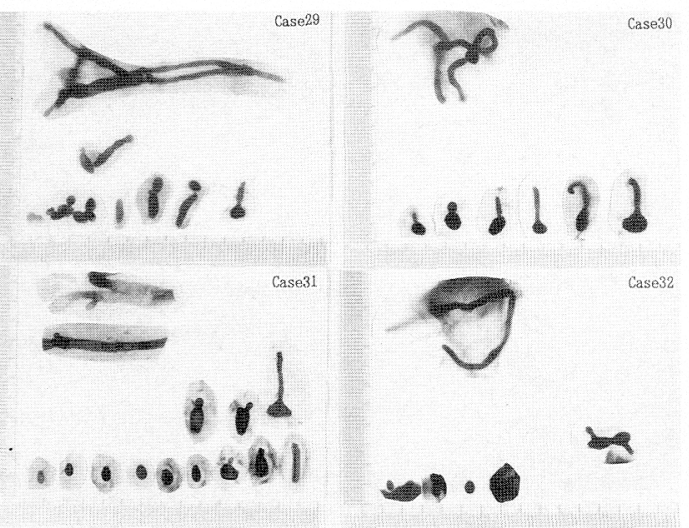

写真 9 酵母細胞の形態, Case 29〜32（C. albicans）

例における酵母細胞の平均長短径比は 1.51 であり, 長径 $4 \mu$ 以上の酵母細胞は $49 \%$ を占めていた。

C. glabrata 分離例：醛母細胞は，すべての症例で

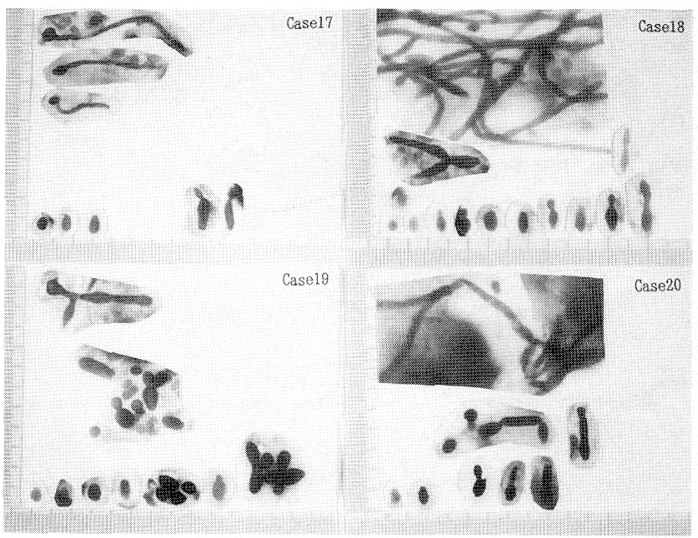

写真 6 酵母細胞の形態, Case 17〜20（C. albicans）

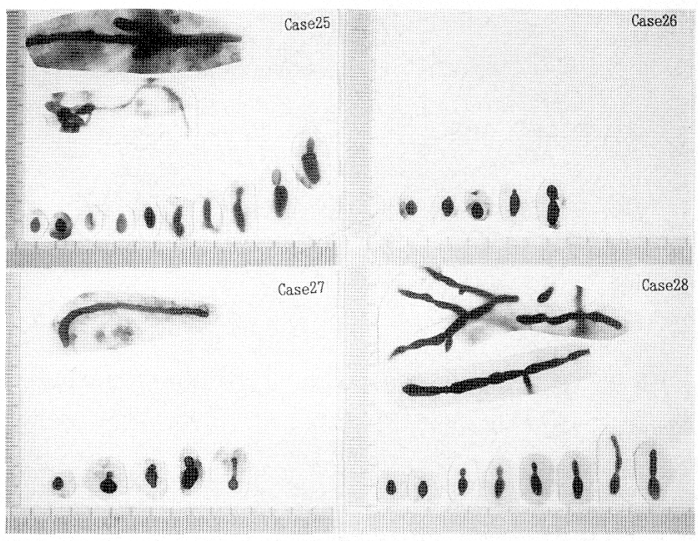

写真 8 酵母細胞の形態, Case 25〜28（C. albicans）

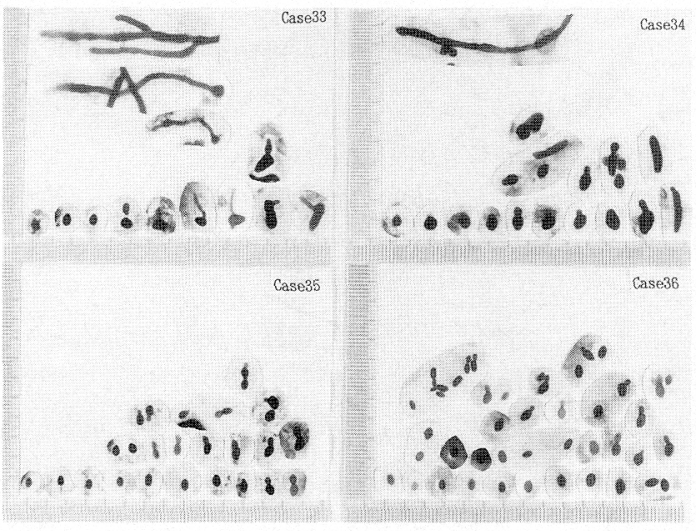

写真 10 酵母細胞の形態, Case 33，34（C. albicans） 35, 36 (C. glabrata)

円形から卵円形で均一な形態を示し，ほとんどが $4 \mu$ 以下の細胞として認められた。顕微計測を行った酵母 細胞の平均長短径比は 1.26 で, $98.5 \%$ は長径 $4 \mu$ 以 


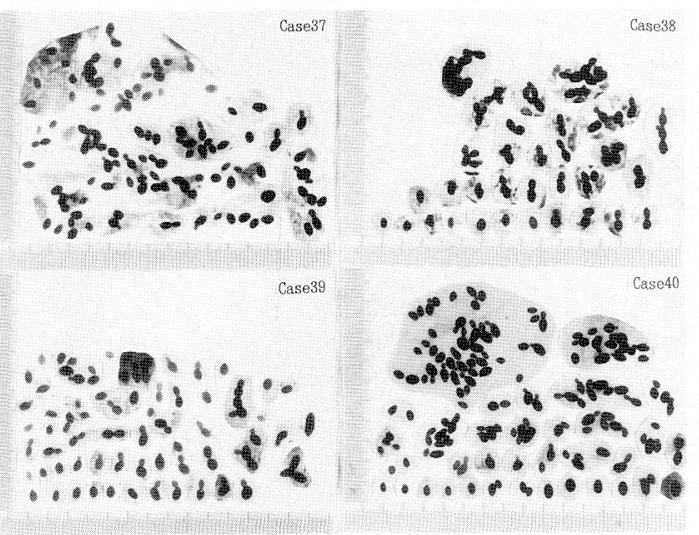

写真 11 酵母細胞の形態, Case 37〜40（C. glabrata）

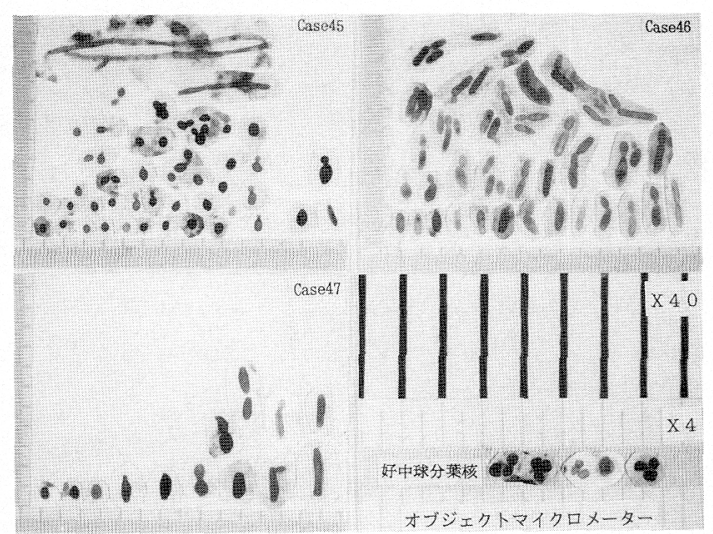

写真 13 酵母細胞の形態, Case 45 (C. glabrata $+C$. albicans) 46, 47 (C. krusei)

下の小型酵母細胞であった。さらに， $5 \mu$ 以上の醳母 細胞はきわめてまれで最大でも $6.5 \mu$ であった。

また，10 例中 1 例に仮性菌系様の構造が観察され た。この症例の標本では, 強拡大で各視野㲹数十〜数 百の $4 \mu$ 以下の酵母細胞がみられ，集簇したものも多 く認められた。その一方で，一部に仮性菌系や発芽管 様構造を有する $5 \mu$ 以上の酵母細胞をみたが，この細 胞は，観察された䣲母細胞の1\% 未満であり，99\% 以上は $5 \mu$ 以下の酵母細胞で，特に $4 \mu$ 以下のものが 97\%を占めていた。

C. albicans，C. glabrata 同時分離例：この症例の 標本では, 強拡大で各視野に数個〜数十個の $4 \mu$ 以下 の酵母細胞がみられた。また，全体で約 20 力所に仮 性菌系を認女，その一部の周囲に 1，2 個の一端がや や膨らんだ 5〜 $6 \mu$ の酵母細胞がみられた。

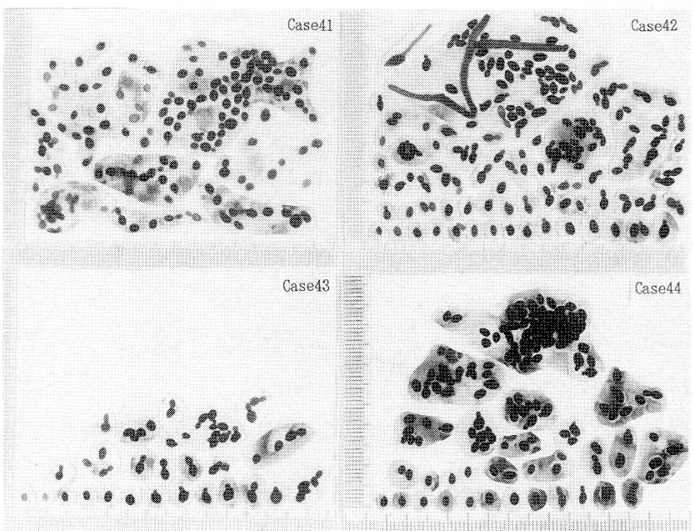

写真 12 酵母細胞の形態, Case 41〜44（C. glabrata) $(42=$ C. albicans 共存? $)$
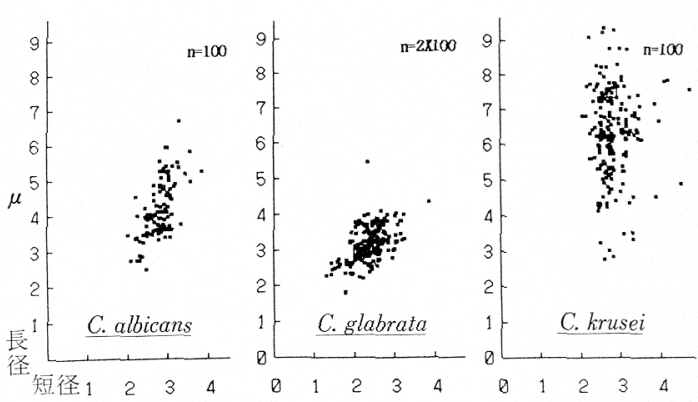

図 1 顕微計測による酵母細胞の大きさの比較

C. krusei 分離例：2 例とも細長い酵母細胞が多かつ た。顕微計測の結果では, 平均長短径比 $2.25,96.5 \%$ が長径 $4 \mu$ 以上の酵母細胞で，そのうち $6 \mu$ 以上の酵 母細胞が $66 \%$ を占めていた。すなわち，C. albicans に比べ長楕円形かつ大型の酵母が主体であった。

\section{IV. 考察}

日常の胵スメア中に酵母様真菌をみることはまれで はなく，そのほとんどはカンジ外属である。比病 原性を示すカンジダ属には, 多くの種”が知られてい るが，胵カンジダ症の原因菌の $90 \%$ 以上は，C． albicans と C. glabrata の 2 者1,2,5,6)である。また，近年 C. glabrata に起因する例が増加傾向にあるという報 告7もある。C. glabrata に起因する胵カンジダ症は, 一般的に症状は軽いものの化学療法に抵抗性を示す症 例が多いと報告されている, 者を迅速に鑑別することは，本症の早期治療と予後を 
推定する上で有意義なものと思われる.

C. glabrata は, 1917 年 Anderson ${ }^{11)}$ によって Cryptococcus glabratus (Anderson) としてはじめて 発表され，1938 年 Lodder 抢よびDe Vries ${ }^{12,13) か ゙ ~}$ Torulopsis glabrata と命名した。 それ以来, N.J.W. Kreger-van Rij 編“The Yeasts”14) でカンジダ属に 吸収された形で属名が変更になるまでは, トルロプシ ス属に分類されていた．この分類上の問題については 形態上の差のみならず, 抗真菌剤に対する感受性の差 異などの多くの点からカンジダ属とは区別すべきであ るという反論もある ${ }^{15)}$.

このC. glabrata に起因する胵カンジダ症について

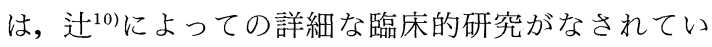
る.しかし, 細胞診におけるこれらの形態学的な検討 はきわめて少ない. 特にC. glabrataに関しては, Bibbo $^{16)}$ の報告を儚矢とし, われわれが渉猟した限り では, 本邦においては佐々木ら ${ }^{9} の$ 報告が最初で, 他 に天神ら $\left.{ }^{17}\right)$ の著書に簡単な記載をみる以外に詳細な記 録はなく，また，これらの報告では酵母細胞の形態的 観察のみでは C. albicans との鑑別はきわめて困難と されている.

ここでは, C. albicans, C. glabrata, C. krusei の 3 種の細胞診標本上での形態的特徴についてとそれら の鑑別点を中心にわれわれの検討結果について若干 の考察を加えたい。

今回の検索で C. albicans は, 仮性菌系や真性菌系 性菌要素を有し，ときに発芽管様構造を示す形態が特 徵であった。これは, 培地上で発育した本菌の一般的 特徴と一致する。また，まれではあるが酵母型のみが 観察される症例でも卵円形を中心に一端がやや膨らん だものが多くさまざまな形態を示し，その多くは長径 $4 \mu$ 以上の酵母細胞として観察された.

一方，C. glabrata は円形から卵円形であり，腟ス メア上でほぼ均一な大きさを示し, 菌系形は存在しな い.また，98.5\% は長径 $4 \mu$ 以下の酵母細胞であり, 長径 $5 \mu$ を越す酵母細胞の出現はほとんどみなかっ た. 以上の形態的特徵は, 細胞診標本上で C. $g l a-$ brata 他のカンジダ属と区別するうえできわめて有 用と考元られた。すなわち, 標本上に観察される真菌 の大半が酵母型の発育をした症例であっても, 長径 $5 \mu$ 以上の酵母細胞が多くみられたならば C. glabrata である可能性がほとんどないと判断できよう。また, 日常の鏡検では好中球の分葉核の一つの大きさが $4 \mu$ 前後であり，これを指標とすることでより簡便な判断
が可能となる.

ところで，C. glabrata と C. albicans が同時分離さ れた 1 例とC. glabrataのみが分離され，その一部に 仮性菌系がみられた 1 例では, 両者ともに $4 \mu$ 以下の 酵母細胞が強拡大で各視野に多数みられ，一部に一端 がやや膨らんだ $5 \sim 6 \mu$ の酵母細胞や仮性菌系が少数 認められたという共通の所見を呈していた。このこと から，この 2 例はいずれも C. glabrata と C. albicans との混合感染例であると推定することができる。ま た，後者で C. glabrataのみが分離された原因として は，C. albicans の腔内での増殖もあったものの，C. glabrataの増殖が圧倒的に優勢であったため, 検体か らの分離ができなかったものと考えたい．このように 長径 $4 \mu$ 以下の小型酵母細胞が優位にみられ, しかも その一方で仮性菌系を見出すことができた場合には， 2 種類の酵母の存在を疑う必要があろう。しかしなが ら,C. albicans が優勢な症例では二者の存在を細胞 䛦標本から推測することはかなり困難と思われた。

C. krusei は, 長短径比 2.25 で $96.5 \%$ が長径 $4 \mu$ 以上の酵母細胞としてみられるが， $6 \mu$ 以上の長楕円 形を示す酵母細胞が $66 \%$ と多く，酵母細胞数の多い 症例では C. albicans との鑑別は比較的容易と思われ た.

カンジダのパパニコロウ染色に対する染色性は不安 定で, カンジダの観察に適した染色とはいい難い.し かし, 酵母細胞は䐋スメアでよくみられる扁平上皮細 胞の表層や中層細胞に混在したり, その周囲にみられ ることが多い. 今回の結果から, 腔カンジダ症の主た る原因菌である C. albicans と C. glabrata を胵スメア 細胞診で鑑別しうる可能性が示唆された。これによっ て胵カンジダ症が臨床的に疑われた場合, 迅速に臨床 への情報提供が可能となると考えられる. また, 細胞 診では真菌の形態を生体内で増殖しているそのままの 形で観察することができ, 組織内の真菌形態観察より も優れた面があるといえよう。木村ら ${ }^{18)}$ はカンジダ膿 瘍における塗抹標本の有用性を報告し, ホルマリン固 定された膿場の塗抹標本でさえもその有用性が発揮さ れると述べている。

真菌の同定は最終的に培養に委ねざるを得ない.し かし，ヒトに感染する病原真菌は約 200 種といわれ, それぞれ特徴的な形態を有しているものが多い.また 日常遭遇する真菌はその数分の 1 以下であり ${ }^{7)}$ ，それ ほど多い種類がみられるわけではない。したがって, これらの形態的特徵を見出せれば細胞診は有用かつ実 
践的な胵カンジダ症の診断法の一つとなりうる.ま た，今回検討したような胵スメアでは真菌が検出され た場合，その大半がカンジダ属であると予測可能であ り，特定の検体については鏡検のみでかなり精度の高 い真菌症の診断が可能であると考えられた.

稿を終えるにあたり，ご指導を賜った帝京大学医真菌研究セ ンター, 内田勝久助教授ならびに元当院臨床検査部細菌検查室, 有田聖子技師に心から感謝の意を表します。

本論文の要旨の一部は第 32 回日本臨床細胞学会総会および第 12 回国際細胞診学会にて発表した.

\section{Summary}

To determine diagnostic accuracy for Candida species in routine cytologic examinations, Candida species found in 47 examinations of routine vaginal smears were morphologically and morphometrically analyzed. The species of Candida had been mycologically confirmed at the same time in each cases.

In cases with $C$. albicans, large yeast cells with a long diameter of more that $4 \mu$ were predominant, and they displayed pseudohyphal and hyphal growth. Conversely, $98.5 \%$ of C. glabrata in vaginal smears had long diameters less than $4 \mu$, and there were no hyphae or pseudohyphae in any of the cases. In cases with $C$. krusei, large yeast cells having a long diameter more than $6 \mu$ were often observed. An elongated oval shape is an important morphological characteristic of $C$. krusei.

Candida species can be identified by a routine cytologic examination based on these morphological characteristics. The accuracy of differentiating between $C$. albicans and $C$. glabrata in especially emphasized.

\section{文献}

1）水野重光. 産婦人科領域の真菌症. 真菌誌 $1967 ; 8: 3$ $\sim 16$.

2）東出香二, 浅井保正, 成田 収, 中西勉, 友田 豊, 神戸俊夫・ほか，妊娠末期婦人における胵真菌症の検 討. 真菌誌 $1978 ； 19 ： 258 \sim 261$.

3）水野重光. 外陰・胵カンジダ症を巡って. 真菌誌 1977 ; $18: 422 \sim 429$.
4）水野重光，高田道夫，山田陽久. 腟内真菌を中心とする 家族内感染. 真菌誌 $1969 ; 10: 122 \sim 125$.

5）山本哲郎, 宮崎敬之, 柳生淳二, 岩瀬一, 片桐信之, 穂垣正暢・ほか, 酵母 Hansenula mrakii の生産するキ ラートキシンを用いたC. albicans と C. glabrataの判 別倍地の作製および，それの産婦人科領域への応用. 真 菌誌 $1988 ； 29 ： 257 \sim 263$.

6）水野重光. 女性性器トルロプシス症の問題点. 産婦人科 治療 $1983 ; 46: 1 \sim 11$.

7）山口英世, 内田勝久. 真菌症診断のための検査ガイド. 東京：栄研化学株式会社, 1994：1９4.

8）水野重光. 女性性器真菌症に対する抗真菌刘の臨床的検 討. 日獨医報 $1985 ； 30 ： 436 \sim 450$.

9）佐々木寿男, 飯田昌義, 青木淳一. Torulopsis glabrata vaginitis とその胵スメア像. 日臨細胞誌 $1976 ； 15 ： 97$ $\sim 101$.

10）辻 邦宏. 産婦人科領域に招ける Torulopsis glabrata に関する研究. 日産婦誌 $1954 ； 11 ： 937 ９ 46$.

11) Anderson, H.W. Yeast-like fungi of the human intestinal tract. J. Infect. Dis. $1917 ; 21: 341 \sim 385$.

12）水野重光，辻 邦宏，Candida に近似の真菌 “Tor uopsis glabrata (Anderson) Lodder et DE Vries 1917” について。産婦の世界 $1956 ; 8 ： 1328 \sim 1339$.

13) Lodder, J., N.F. DE Vries. Some notes on Torulopsis glabrata (Anderson) nov. comb. Mycopathologia $1938 ; 1: 98 \sim 103$.

14) N.J.W. Kreger-ven Rij. The yeasts a taxonomic study third revised and enlarged edition. Amsterdam : Elsevier Science Publishers B.V., 1984: 687 688.

15）岩田和夫. 医真菌学関係用語についての意見と提案の 二，三抢よび改版 “The Yeasts”における Torulopsis $\rightarrow$ Candidaへの変更について. 真菌誌 $1984 ; 25: 182$ $\sim 186$.

16) Bibbo, M., Wied, G.L., Transparencies and Explanatory Text (Vol. 9) Idetification of inflammatory reactions, tissue repair, viral infections and microbiologic classifications in cytologic specimens of the female reproductive tract. Chicago: Tutorials of Cytology, 1973.

17）武田 敏，大内義智. カンジダ胵炎，外陰炎. 天神美夫 偏，新婦人科細胞診断学一日米欧の比較を中心に一。東 京：医学書院, $1977 ： 190 \sim 193$.

18）木村雅友, 前倉俊治, 門田永治, 尾鼻康朗, 坂谷邦康. カンジダ膿瘍における塗抹標本作製の有用性. 日臨細胞 誌 $1989 ； 28 ： 455 \sim 458$. 